\title{
Incidence of Collar Rot of Groundnut in Rajasthan and its Management
}

Tejpal Bajaya, Mamta Bajya, R.P. Ghasolia, Manisha Shivran

10.18805/LR-4864

\begin{abstract}
Background: Groundnut (Arachis hypogaea L.) is an important legume crop of tropical and sub-tropical areas of the world. This crop suffers from several diseases like early leaf spot, late leaf spot, rust, groundnut bud necrosis, peanut clump and collar rot etc. But collar rot caused by Aspergillus niger van Teighem is one of the most important seed and soil borne diseases causing huge economic (40-50 per cent) loss in India and abroad.

Methods: A roving survey was conducted to assess the incidence of collar rot in eight major groundnut growing districts of western Rajasthan i.e. Bikaner, Jodhpur, Churu, Jalore, Jaipur, Sikar, Nagaur and Dausa during Kharif 2018. A field experiment was carried out for two consecutive years (2019 and 2020) to manage the disease through altering micro-climate under canopy with six levels of seed rates $(80,85,90,95,100$ and $105 \mathrm{~kg} / \mathrm{ha})$.

Result: Our investigations cleared that this disease is prevalent in all the 200 fields surveyed in eight districts of Rajasthan with 22.99 per cent overall disease incidence which varied from 17.84 to 32.38 per cent with monetary losses. Maximum disease incidence was recorded in Jaipur (28.85\%) district while it was lowest in Nagaur district $(20.15 \%)$. Higher disease reduction (12.97\%) with increased pod yield $(27.65 \%)$ was observed with higher seed rate of $105 \mathrm{~kg} / \mathrm{ha}$ as compared to standard recommended seed rate $(80 \mathrm{~kg} / \mathrm{ha})$ as this pathogen is favoured by higher temperature and low soil moisture, dense canopy provides shade that increases humidity under the cropped area and lowers temperature. As a result of this, plant mortality can be compensated by increasing plant population through seed rate, as it modifies the microclimate and generate an environment which is less favourable for developing collar rot disease of groundnut.
\end{abstract}

Key words: Aspergillus niger, Collar rot, Disease incidence, Groundnut, Seed rate, Survey.

\section{INTRODUCTION}

Groundnut (Arachis hypogaea L.), is an important legume crop of tropical and sub-tropical areas of the world, described in 1753 by Linnaeus (Pattee and Young, 1982). Groundnut kernels contain about 26 per cent protein, 48 per cent edible oil, 20 per cent carbohydrates and three per cent fiber and also rich in calcium, thiamine and niacin (Haveri 2017). As a source of edible oil, it finds its prime utility, as a consequence of it, this crop is gaining the status of "king of oil seed crops" (Reddy 1976). Additionally, in association with symbiotic nitrogen-fixing bacteria, it fixes and enriches the soil with $80-160 \mathrm{~kg} \mathrm{~N} / \mathrm{ha}$ per season (Alam et al., 1988).

In India, the total coverage area under this crop is 39.31 lakh hectares, production is 6.86 million tonnes with an average productivity of $1745 \mathrm{~kg} /$ hectare (Anonymous, 2019). Rajasthan stands second position in terms of area and production. The cultivation of groundnut is well adapted to the conditions prevailing in Rajasthan and is cultivated in about 7.34 lakhs hectares with annual production 1.612 million tonnes and productivity of $2195 \mathrm{~kg} /$ hectare (Anonymous, 2019-20).

Several abiotic and biotic factors affect the growth and development of groundnut leading to qualitative and quantitative yield losses. Diseases are most damaging and major limiting factors that cause the largest economic losses in profitable cultivation of this crop in Rajasthan. Amongst fungal diseases, collar rot of groundnut also known as seedling blight caused by Aspergillus niger van. Teighem is one of the important seed and soil borne diseases. Pathogenis a well known polyphagous, ubiquitous, non-
Department of Plant Pathology, SKN College of Agriculture, Jaipur-303 329, Rajasthan, India.

Corresponding Author: Mamta Bajya, Department of Botany, Punjab Agricultural University, Ludhiana-141 004, Punjab, India. Email: bajyamamta57@gmail.com

How to cite this article: Bajaya, T., Bajya, M., Ghasolia, R.P. and Shivran, M. (2022). Incidence of Collar Rot of Groundnut in Rajasthan and its Management. Legume Research.DOI: 10.18805/ LR-4864.

Submitted: 04-01-2022 Accepted: 08-02-2022 Online: 21-02-2022

target and the most destructive soil and seed inhabiting fungus (Vimalkumar and Saifulla, 2017). This disease was first reported by Jochem (1926) from Java. In Rajasthan, Bakhetia (1983) had reported disease incidence up to 50.00 per cent. Dighule et al. (2018) estimated yield losses in Maharashtra from 28.00 to 50.00 per cent due to collar rot of groundnut caused by Aspergillus niger van. Teighem.

Collar rot of groundnut prominently is distributed in countries with tropical and sub tropical climates where high temperature prevails during the rainy season and it is present in all most all the groundnut growing areas of the world. The loss due to this disease was reported upto 40-50 per cent (Chahal et al., 1974). The pathogen seems to have adaptability to higher temperature and the disease occurs during July to September, which is particularly severe at preand post-emergence stages causing considerably losses to the yield (Kumari, 2015). 


\section{MATERIALS AND METHODS Survey}

Roving method of survey was followed to assess the incidence of collar rot disease of groundnut. (Table 1) The survey of major groundnut growing districts of Rajasthan i.e. Bikaner, Jodhpur, Churu, Jalore, Jaipur, Sikar, Nagaur and Dausa was conducted during 2018 to record incidence of disease and to collect diseased samples. In each district, five villages of a Tehsil were visited. In each village, five farmer's field was surveyed for disease incidence. Samples from each field was collected and brought to the laboratory. The disease incidence was recorded in $3 \mathrm{~m} \times 3 \mathrm{~m}$ marked area in each field from five locations and per cent disease incidence (PDI) was calculated by counting the diseased and the total number of plants per spot. The plant showing collar rot symptoms was considered as a diseased plant.

\section{Effect of seed rate}

The present investigation was carried out during Kharif 2019 and 2020 at the Agronomy Farm and Department of Plant Pathology, S.K.N. Collage of Agriculture, Sri Karan Narendra Agriculture University, Jobner, Rajasthan. Jobner is situated at latitude of $26^{\circ} 5^{\prime} \mathrm{N}$, longitude of $75^{\circ} 20^{\prime} \mathrm{E}$ and altitude of 427 meters above MSL (mean sea level). This region falls under semi-arid eastern plain (Agro Climatic Zone- III A) of Rajasthan. Seed rate is considered very important and has been shown to have considerable effects on several soil borne diseases. Additional or increased plant population may compensate with succumbed plants at early stage by the disease. To understand the role of plant population (by using different seed rates) on incidence and development of collar rot of groundnut, the experiment was carried out under artificial inoculum with susceptible groundnut variety RG382. Inoculum, multiplied on sorghum grains was added in furrows at $20 \mathrm{~g} / \mathrm{m}$ row length at the time of sowing. Six levels of seed rates $(80,85,90,95,100$ and $105 \mathrm{~kg} / \mathrm{ha})$ was used under simple RBD with four replications in $2.1 \mathrm{~m} \times 2 \mathrm{~m}$ plots. The plots were irrigated as per requirement with uniform amount of water. Observations on per cent disease incidence was recorded 45 days after sowing and after 10 days of harvest pod yield was recorded.

\section{RESULTS AND DISCUSSION Survey}

Our investigations cleared that collar rot disease incidence (Table 2) was more severe in Jaipur district (28.85\%) followed by Sikar (24.94\%), Jalore $(23.71 \%)$ and Jodhpur $(22.60 \%)$. Among all the surveyed villages (Table 1 ) the maximum incidence $(32.38 \%)$ of collar rot was noted in the field of Babu Lal farmer belonging to Khejroli village of Chomu tehsil in Jaipur district and minimum (17.84\%) in Shesma Ka Bas village of Kuchaman city in Nagaur district. As per literature reviewed, this is the premier report on systematic assessment of the disease in the different districts of Rajasthan state which is the for most aspect for a plant pathologist to carry out any further study on the disease development and management. Our findings are in accordance with the results of earlier researchers (Joshi, 1969; Aulakh and Sandhu, 1970; Kumari and Singh, 2016; Meena et al. 2019). In Gujarat state of India, Joshi (1969) has been surveyed groundnut growing areas and reported seedling blight incidence ( $A$. niger) up to 50.00 per cent in diseased fields while Aulakh and Sandhu (1970) have also been assessed mortality ( $A$. niger) of groundnut plants from 40.00 to 50.00 per cent. Kumari and Singh (2016) have also been surveyed groundnut fields in Sikar and Jaipur districts of Rajasthan and recorded 13.09 to 52.00 per cent disease incidence under natural field conditions. Similar work has also been carried out by Veena et al. (2019) in five districts of Andhra Pradesh and noticed economic losses to the groundnut by collar rot disease. Recently similar work has been carried out by Saran et al (2020) that survey was conducted in major groundnut growing areas of different tehsil of Jodhpur district, Rajasthan during kharif 2019 to assess the distribution and the incidence of collar rot diseases. The highest incidences of collar rot were observed in Phalodi (15.31\%). Whereas, least collar rot incidence was observed $(10.0 \%)$ in Tewari.

\section{Effect of seed rate}

Effect of plant population (by using different seed rates) on incidence of collar rot of groundnut were recorded under artificial soil inoculation conditions during Kharif 2019 and Kharif 2020. Plant population had influence on collar rot incidence of groundnut during both the years of study. Analysis of data of Kharif 2019 (Table 3) revealed that maximum disease reduction $(13.73 \%)$ over check was observed with seed rate of $105 \mathrm{~kg} / \mathrm{ha}$ followed by $100 \mathrm{~kg} / \mathrm{ha}$ $(12.87 \%)$ while it was lowest $(6.95 \%)$ with $85 \mathrm{~kg} / \mathrm{ha}$ as compared to standard check $(80 \mathrm{~kg} / \mathrm{ha})$. The disease incidence of seed rate of $105 \mathrm{~kg} / \mathrm{ha}$ and $100 \mathrm{~kg} / \mathrm{ha}$ were found significantly superior to standard check $(80 \mathrm{~kg} / \mathrm{ha})$. Maximum significant increase in pod yield $(27.71 \%)$ over check was recorded in seed rate of $105 \mathrm{~kg} / \mathrm{ha}$ followed by $100 \mathrm{~kg} / \mathrm{ha}(23.89 \%)$ while it was lowest $(12.42 \%)$ in seed rate of $85 \mathrm{~kg} / \mathrm{ha}$ as compared to standard check $(80 \mathrm{~kg} / \mathrm{ha})$. Analysis of two years pooled data (Table 3 ) revealed that maximum disease reduction $(12.97 \%)$ over standard check was observed with seed rate of $105 \mathrm{~kg} / \mathrm{ha}$ followed by 100 $\mathrm{kg} / \mathrm{ha}(11.89 \%)$ while it was lowest $(4.72 \%)$ with $85 \mathrm{~kg} / \mathrm{ha}$ as compared to standard check $(80 \mathrm{~kg} / \mathrm{ha})$. The disease incidence of seed rate of $105 \mathrm{~kg} / \mathrm{ha}$ was found significantly superior to standard check ( $80 \mathrm{~kg} / \mathrm{ha}$ ). Maximum significant increase in pod yield (27.65\%) over check was recorded in seed rate of $105 \mathrm{~kg} / \mathrm{ha}$ followed by $100 \mathrm{~kg} / \mathrm{ha}(23.49 \%)$ while it was lowest $(10.87 \%)$ in seed rate of $85 \mathrm{~kg} / \mathrm{ha}$ as compared to standard check $(80 \mathrm{~kg} / \mathrm{ha})$. Although, the disease was not controlled in appreciable amount but increased yield was recorded, it was most probably due to increased plant population by compensatory effect to the plant mortality. Maximum disease reduction (Table 3) (12.97\%) and increased seed yield (27.65\%) were recorded with $105 \mathrm{~kg} /$ ha seed rate in comparison to recommend seed rate @ 80 
$\mathrm{kg} / \mathrm{ha}$. Decrease in disease incidence and increase in pod yield are due to complimentary changes in microclimate of field due to variation in plant population by different seed rates. Our findings are parallel to the results of Kishore et al. (2007) who concluded that collar rot disease of groundnut is more severe in soils with low moisture and high temperature. Singh (2010) who concluded that wider plant geometry provides good ventilation and sunlight that result in decreased soil moisture and enhanced temperature in the crop; as a result, the pathogens that thrive in high humidity and high temperature are discouraged. Winter et al. (2013) observed that cultural practices may directly

Table 1: Places of sample collection and disease incidence in surveyed fields in eight districts of Rajasthan.

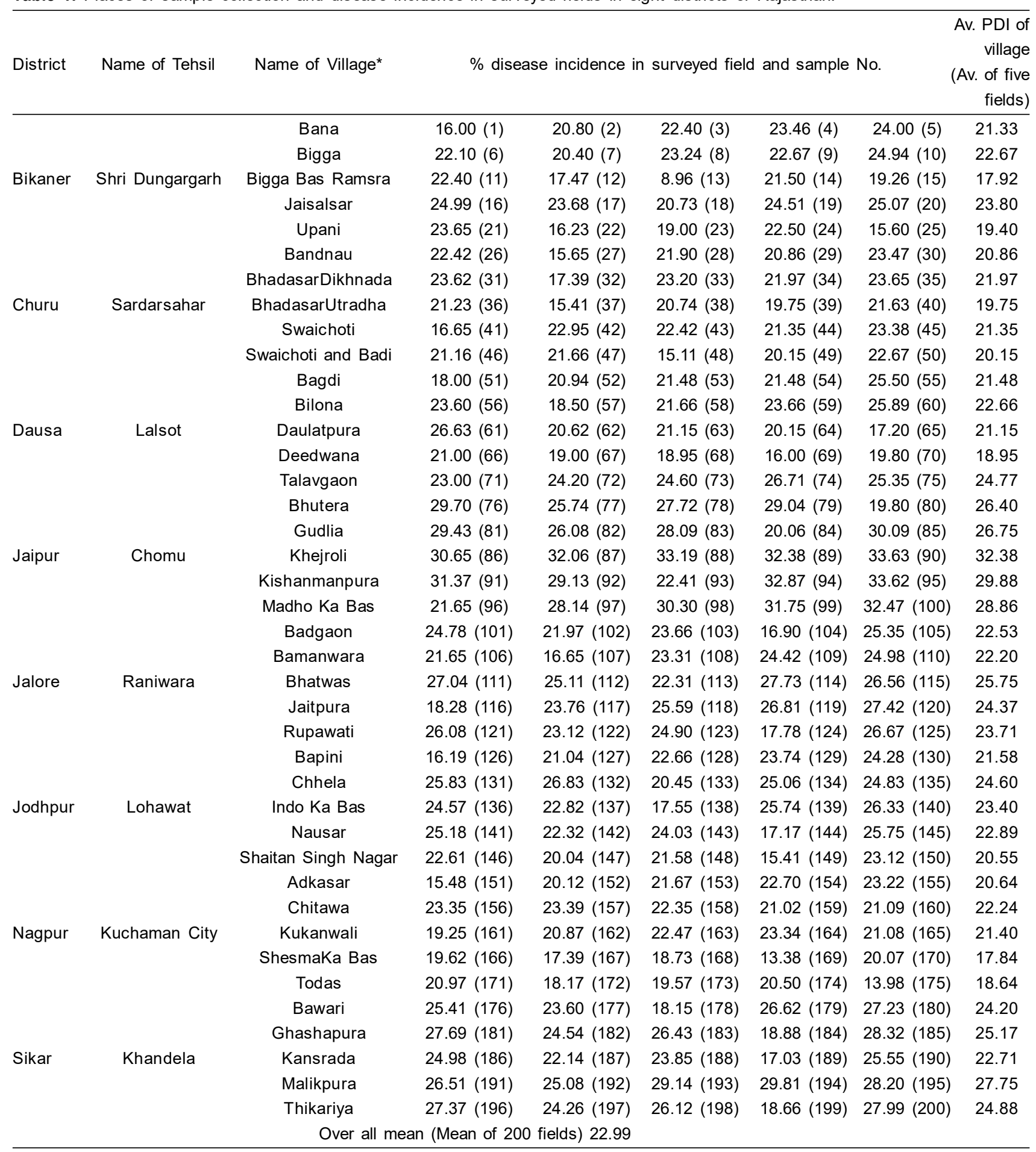

PDI= Per cent disease incidence. 
Incidence of Collar Rot of Groundnut in Rajasthan and its Management

Table 2: Details of different isolates of $A$. niger collected during survey from eight districts of Rajasthan.

\begin{tabular}{|c|c|c|c|c|c|c|}
\hline \multirow[b]{2}{*}{ District } & \multirow[b]{2}{*}{ Tehsil } & \multicolumn{3}{|c|}{ Details of field chosen for establishing isolate ${ }^{* *}$} & \multirow{2}{*}{$\begin{array}{l}\text { Representative isolate } \\
\text { of district and their } \\
\text { code no. }\end{array}$} & \multirow{2}{*}{$\begin{array}{l}\text { Av. PDI of } \\
\text { district (Av. } \\
\text { of } 25 \text { fields) }\end{array}$} \\
\hline & & Village & $\begin{array}{l}\text { Name of farmer } \\
\text { and sample no. }\end{array}$ & PDI of field & & \\
\hline Bikaner & Shri Dungargarh & Jaisalsar & $\begin{array}{l}\text { Munni Ram Jat, } \\
\text { Sample No. } 20\end{array}$ & 25.07 & ANBK 01 & 21.04 \\
\hline Churu & Sardarshahar & $\begin{array}{l}\text { Bhadasar } \\
\text { Dikhnada }\end{array}$ & $\begin{array}{l}\text { RakeshJakhar, } \\
\text { Sample No. } 35\end{array}$ & 23.65 & ANCH 02 & 20.82 \\
\hline Dausa & Lalsot & Talavgaon & $\begin{array}{l}\text { MurariMeena } \\
\text { Sample No. } 74\end{array}$ & 26.71 & ANDA 03 & 21.80 \\
\hline Jaipur & Chomu & Khejroli & $\begin{array}{c}\text { Babu Lal } \\
\text { Sample No. } 90\end{array}$ & 33.63 & ANJP $04^{*}$ & 28.85 \\
\hline Jalore & Raniwara & Bhatwas & $\begin{array}{l}\text { Sita Ram Suthar } \\
\text { Sample No. } 114\end{array}$ & 27.73 & ANJL 05 & 23.71 \\
\hline Jodhpur & Lohawat & Chhela & $\begin{array}{l}\text { Jalam Singh, } \\
\text { Sample No. } 132\end{array}$ & 26.83 & ANJD 06 & 22.60 \\
\hline Nagaur & Kuchaman City & Chitawa & $\begin{array}{c}\text { Bansi Lal } \\
\text { Sample No. } 157\end{array}$ & 23.39 & ANNG 07 & 20.15 \\
\hline Sikar & Khandela & Malikpura & $\begin{array}{c}\text { Naveen Kajla } \\
\text { Sample No. } 194\end{array}$ & 29.81 & ANSK 08 & 24.94 \\
\hline
\end{tabular}

*This isolate was selected for common experiments. ${ }^{* *}$ Representative isolate of each district was established from the field showing highest PDI.

Table 3: Effect of seed rate on collar rot incidence and yield of groundnut.

\begin{tabular}{|c|c|c|c|c|c|c|c|c|c|c|c|c|}
\hline \multirow{2}{*}{$\begin{array}{l}\text { Seed } \\
\text { rate } \\
(\mathrm{Kg} / \mathrm{ha})\end{array}$} & \multicolumn{6}{|c|}{ PDI* } & & \multicolumn{5}{|c|}{ Yield* (q/ha) } \\
\hline & 2019 & $\begin{array}{l}\text { Per cent } \\
\text { disease } \\
\text { reduction }\end{array}$ & 2020 & $\begin{array}{l}\text { Per cent } \\
\text { disease } \\
\text { reduction }\end{array}$ & Pooled & $\begin{array}{l}\text { Per cent } \\
\text { disease } \\
\text { reduction }\end{array}$ & 2019 & $\begin{array}{c}\text { Per cent } \\
\text { yield } \\
\text { increase }\end{array}$ & 2020 & $\begin{array}{c}\text { Per cent } \\
\text { yield } \\
\text { increase }\end{array}$ & Pooled & $\begin{array}{c}\text { Per cent } \\
\text { yield } \\
\text { increase }\end{array}$ \\
\hline $80 \#$ & $\begin{array}{c}54.60 \\
(47.64)\end{array}$ & 0 & $\begin{array}{c}56.86 \\
(48.94)\end{array}$ & 0 & $\begin{array}{c}55.73 \\
(48.29)\end{array}$ & 0 & 15.70 & - & 14.10 & - & 14.90 & - \\
\hline 85 & $\begin{array}{c}50.80 \\
(45.46)\end{array}$ & 6.95 & $\begin{array}{c}55.40 \\
(48.10)\end{array}$ & 2.57 & $\begin{array}{c}53.10 \\
(46.78)\end{array}$ & 4.72 & 17.65 & 12.42 & 15.38 & 9.08 & 16.52 & 10.87 \\
\hline 90 & $\begin{array}{c}49.79 \\
(44.88)\end{array}$ & 8.80 & $\begin{array}{c}53.38 \\
(46.94)\end{array}$ & 6.12 & $\begin{array}{c}51.59 \\
(45.91)\end{array}$ & 7.42 & 17.90 & 14.01 & 15.90 & 12.77 & 16.90 & 13.42 \\
\hline 95 & $\begin{array}{c}48.57 \\
(44.18)\end{array}$ & 11.04 & $\begin{array}{c}51.10 \\
(45.63)\end{array}$ & 9.39 & $\begin{array}{c}49.84 \\
(44.91)\end{array}$ & 10.57 & 18.35 & 16.88 & 16.81 & 19.22 & 17.58 & 17.99 \\
\hline 100 & $\begin{array}{c}47.57 \\
(43.61)\end{array}$ & 12.87 & $\begin{array}{c}50.63 \\
(45.36)\end{array}$ & 10.95 & $\begin{array}{c}49.10 \\
(44.48)\end{array}$ & 11.89 & 19.45 & 23.89 & 17.35 & 23.05 & 18.40 & 23.49 \\
\hline 105 & $\begin{array}{c}47.10 \\
(43.34)\end{array}$ & 13.73 & $\begin{array}{c}49.90 \\
(44.94)\end{array}$ & 12.13 & $\begin{array}{c}48.50 \\
(44.14)\end{array}$ & 12.97 & 20.05 & 27.71 & 18.00 & 27.66 & 19.02 & 27.65 \\
\hline SEm \pm & 1.43 & - & 1.32 & - & 1.43 & - & 0.82 & - & 0.72 & - & 0.75 & - \\
\hline$C D(p=0.05)$ & ) 4.02 & - & 3.98 & - & 4.10 & - & 2.51 & - & 2.23 & - & 2.33 & - \\
\hline CV (\%) & 7.22 & - & 6.86 & - & 8.27 & - & 7.42 & - & 7.54 & - & 8.56 & - \\
\hline
\end{tabular}

${ }^{*}$ Average of four replications, Figures given in parenthesis are angular transformed as: DEGREES [ASIN \{SQRT (\% VALUE/100)\}]. \# Standard seed rate $(80 \mathrm{~kg} / \mathrm{ha})$ as per POP of the Jaipur division of the state Rajasthan, Spreading type variety (RG-382) used during experimentation. 
or indirectly affect inoculum load of soil borne plant pathogens and the incidence of their consequential root rot diseases. As $A$. niger is favoured by higher temperature and low soil moisture, dense canopy provides shade, increases humidity under the cropped area, delays drying of soil under the plants canopy, prevent aeration and radiation and lowers temperature. These conditions are un-favorable for collar rot disease. It was observed by this study that, the dense planting can be the coolest, wettest and had slightly low incidence of disease whereas the wider planting may be the warmest, driest and had higher collar rot disease. It was also cleared that the incidence of collar rot was coupled with variations in the microclimate of the crop. As a result of this, plant mortality can be compensated by increasing plant population through seed rate, as it modifies the microclimate and generate an environmenst which is less favourable for developing collar rot disease of groundnut.

\section{CONCLUSION}

During survey, maximum collar rot incidence was observed in Jaipur (28.85\%) and minimum in Bikaner (21.04\%) district while overall mean disease incidence of eight districts was 22.99 per cent covering 200 fields of major groundnut growing districts of Rajasthan. Among six levels of seed rate $(80,85,90,95,100$ and $105 \mathrm{~kg} / \mathrm{ha})$, higher disease reduction with increased pod yield was observed with seed rate of $105 \mathrm{~kg} / \mathrm{ha}$ as compared to standard recommended seed rate $(80 \mathrm{~kg} / \mathrm{ha})$.

\section{ACKNOWLEDGEMENT}

The authors are thankful to The Dean, SKNCOA, Jobner and The Head, Department of Plant Pathology and Agronomy, SKNCOA (SKNAU), Jobner, (Jaipur), Rajasthan for providing all the required facilities to carry out these experiments successfully.

Conflict of interest: None.

\section{REFERENCES}

Alam, K.B., Bari, M.A., Talukdar, M.I. (1988). Effect of fungicide on the control of Tikka disease of groundnut. Bangladesh. Journal of Agricultural Research. 5(2):17-20.

Anonymous (2019). Kharif-2019. Survey of groundnut cropexecutive summary. http://www.iopepc.org/misc/ pp. 1-24.

Anonymous. (2019-20). Commissionerate of Agriculture, Rajasthan, Jaipur. pp. 1-12, www. agriculture.rajasthan.gov.in.

Aulakh, K.S. and Sandhu, R.S. (1970). Reaction of groundnut varieties against Aspergillus niger. Plant Diseses Reporter. 54(4): 337-338.

Bakhetia, D.R.C. (1983). Control of white grub (Holotrichia consenenguinea) and collar rot (Aspergillus niger) of groundnut sown in different dates in Punjab. Indian Journal of Agricultural Sciences. 53(9): 846-850.

Chahal, A.S., Dutt, S., Chohan, J.S. (1974). Varietal resistance in groundnut (Arachis hypogaea L.) to collar rot (Aspergillus niger) in Punjab state. Journalof Research Punjab Agricultural University. 11(2): 200-203.
Dighule, S.B., Gawade, S.B., Deshmukh, G.P., Mahajan, S.B. (2018). Effect of seed treatment of chemicals for management of collar rot of groundnut (Arachis hypogaea L.). Trends in Bioscience. 11(6): 800-801.

Haveri, N. (2017). Studies on diversity of Sclerotium rolfsii Sacc. and induced systemic resistance in groundnut (Arachis hypogaea L.) against stem rot pathogen. Prof. Jayashankar Telangana State Agricultural University, Ph.D. thesis.

Jain, A.C. and Nema, K.G. (1952). Aspergillus blight of groundnut seedlings. Sci. Cult. 17:348.

Jochem, S.C.J. (1926). Aspergillus niger on groundnut. Indisch Culturen (Teysmannia). 11:325-326.

Joshi, D.H. (1969). Studies on the seed microflora of groundnut, cotton, bajra, wheat and sesame under Gujarat condition. M.sc (Agri). thesis, Gujrat Agricultural University, Sardar Krishinagar, Dantiwada, pp 126.

Kishore, G.K., Pande, S., Harish, S. (2007). Evaluation of essential oils and their components for broad-spectrum antifungal activity and control of late leaf spot and crown rot diseases in peanut. Plant Diseases. 91:375-379.

Kumari, M. (2015). Variability and management of Aspergillus niger Van. Tieghem causing collar rot of groundnut (Arachis hypogaea L.). M.Sc. thesis. Sri Karan Narendra Agriculture University, Jobner.

Kumari, M. and Singh, M. (2016). Morphological and pathogenic variabilities among Aspergillus niger isolates associated with groundnut (Arachis hypogea L.) Annals of Plant Protection Science. 24(2): 364-368.

Meena R.L., Jat, B.L., Babita D. (2019). Status of Collar Rot in Groundnut and Impact of Demonstrations on its Management in Dausa District of Rajasthan. International Journal of Agriculture Sciences. 11(22): 9199-9201.

Pattee, H. and Young, G.T. (1982). Peanut Science and Technology. Yoakum, Texas 77995, USA.

Reddy, M.V. (1976). Crop management of groundnut, irrigated and dry crop. Paper read at $9^{\text {th }}$ annual workshop-cum-seminar on an India Coordinated Research Project on Oil seed Crops held at Nagpur on 5-9th April.

Saran, M.K., Ram, D., Verma, J.R., Kumawat, M.M., Netajit, L. (2020). Survey for the Assessment of Groundnut Collar Rot Disease Incidence in Major Groundnut Growing Areas of Jodhpur, Rajasthan, India. International Journal of Current Microbiology and Applied Sciences. 9(9): 1162-1166.

Singh, R.P. (2010). Plant Pathology. Kalyani Publishers, Ludhiana, Disease Management: Regulatory Methods, Cultural Practices and Physical Methods. pp 234-243.

Veena, G.A., Padmodaya, B., Devi, R.S.J., Manjula, K., Naidu, G.M. (2019). Survey for disease incidence of groundnut collar rot, stem rot and root rot in Ananthapur, Kadapa, Chitttoor, Kurnool and Nellore districts of Andhra Pradesh. International Journal of Chemical Studies. 7(3): 4932-4934.

Vimal Kumar, C. and Saifulla, M. (2017). Management of collar rot of groundnut caused by Aspergillus niger van Teighem in in vitro and in vivo conditions. Special Symposium on "Microbial Antagonists and Their Role in Biological Control of Plant Diseases" during October 5-7, 2017.

Winter, P.S., Bowman, C.E., Villani, P.J., Dolan, T.E. and Hauck, N.R. (2013). Systemic acquired resistance in moss: Further evidence for conserved defense mechanisms in plants. PloS One 9(7): pp 101880. 